\title{
El abuso del Derecho de Información fuera de Junta en las Sociedades Anónimas y las limitaciones a su ejercicio(*) $^{*}$
}

\section{The Abuse of the Right to Information Outside of Board in Corporation and the Limitations to its Exercise}

\author{
Eduardo Leturia ${ }^{(*)}$ \\ Fernandez, Heraud \& Sanchez Abogados
}

\begin{abstract}
Resumen: El artículo 52-A de la Ley General de Sociedades peruana incorporó el derecho de información de los accionistas fuera de las Juntas Generales de Accionistas para la sociedades anónimas. En dicho artículo, este derecho se encuentra limitado por dos aspectos: (i) que para su ejercicio debe ser solicitado por accionistas que representen no menos del cinco por ciento (5\%) del capital pagado y (ii) que la información requerida no verse sobre hechos reservados o de asuntos cuya divulgación pueda causar daños a la sociedad. Sin embargo, aunque la citada norma no lo señale expresamente, otra restricción es que el ejercicio del mismo no puede darse de manera abusiva. El presente artículo desarrolla las limitaciones del derecho de información fuera de Junta y el abuso de dicho derecho, cuestionando si es un derecho a auditar o si obliga a la administración a preparar información requerida por los accionistas.
\end{abstract}

Palabras clave: Derecho de Información fuera de Junta - Sociedad Anónima - Junta General de Accionistas - Perú

\begin{abstract}
In Peru, article 52-A of the General Corporation Law incorporated the shareholders' right to information outside of the General Shareholders Board for companies. In said article, this right is limited by two aspects: (i) that it must be requested by shareholders representing no less than five percent (5\%) of the paid capital and (ii) that the required information must not compromise reserved facts or matters whose disclosure may damage the company. Although the aforementioned law does not explicitly indicate it, another restriction is that said right cannot be exercised in an abusive manner. This paper discusses the limitations to the shareholders' right to information outside the General Shareholders Board and the abuse of said right, questioning whether it needs to be audited or if it compels the administration to prepare information required by the shareholders.
\end{abstract}

Keywords: Right to Information Outside of Board - Corporations - General Shareholders Board - Peru

(*) Nota del Editor: El artículo fue recibido el 10 de noviembre y aprobada su publicación el 23 de noviembre de 2018.

${ }^{* *}$ Abogado por la Universidad de Lima. Magíster en Derecho Empresarial por la Universidad de Lima. Magíster en Administración Estratégica de Empresas por la Pontificia Universidad Católica del Perú. Máster en Administración de Empresas por la Escuela de Negocios de Maastricht, Holanda. Profesor de Derecho Societario en la Maestría en Derecho Empresarial de la Escuela de la Posgrado de la Universidad de Lima. Socio de Fernández, Heraud \& Sánchez Abogados. Correo electrónico: eleturia@fhsabogados.com 


\section{Introducción}

Imagínense a un accionista que le exige al Gerente General un reporte sobre la estructura de costos de alguno de los productos que fabrica la compañía o que le demanda ingresar a una de las plantas de la compañía para observar si el personal está utilizando equipos de protección personal. Ahora piensen en un accionista que llama al Gerente General dos veces por semana a solicitarle información actualizada sobre las ventas; $u$ otro que desea un listado de los gastos de movilidad de los últimos diez meses de todo el personal. ¿Sería inconcebible, no?

En efecto, la administración de una sociedad anónima no debería distraerse en cumplir con los requerimientos de accionistas que solicitan información de manera desmesurada y desproporcionada. Sin embargo, alguno podría interpretar que el artículo 52-A de la Ley General de Sociedades le otorga esos "derechos de información", pues dicha norma solamente requiere que el derecho allí regulado sea ejercido por accionistas que tengan por los menos el cinco por ciento (5\%) del capital pagado y que la información requerida no sea sensible.

Es por ello que mediante el presente documento desarrollaremos la tesis de que el derecho de información de los accionistas fuera de Junta, regulado por el artículo 52-A de la Ley General de Sociedades, no solamente se encuentra limitado por lo señalado anteriormente, sino que, adicionalmente, el ejercicio del mismo no puede darse de manera abusiva. Es innegable el derecho de información que tienen los accionistas de una sociedad anónima, no solamente para estar informados de los temas de agenda a raíz de una convocatoria a Junta General de Accionistas, sino también para que se ejerza dicho derecho aun cuando no se haya convocado al órgano supremo de la sociedad. Para lograr ese objetivo, sería aconsejable que la misma administración establezca una política de información al accionista, para que este pueda acceder de manera ordenada, oportuna, equitativa y previsible a la información relevante de la sociedad.

\section{El derecho de información de los accionistas de las sociedades anónimas}

El derecho de información es uno de los derechos fundamentales de los accionistas de las sociedades anónimas y está recogido en diversos artículos de la Ley 26887, Ley General de Sociedades (en adelante, "LGS") publicada el 9 de diciembre de 1997. Como se observará a continuación, en dichos artículos de la LGS se le otorga al accionista de una sociedad anónima la posibilidad de obtener la información que le permita emitir un voto o fiscalizar oportuna y adecuadamente la gestión de la sociedad. En otras palabras, el derecho de información viene a ser un instrumento para poder ejercer otros derechos de los accionistas de la sociedad anónima.

\subsection{El derecho a fiscalizar de los accionistas con derecho a voto}

En efecto, el numeral 3 del artículo $95^{(1)}$ de la LGS confiere a los accionistas con derecho a voto la prerrogativa de fiscalizar en la forma establecida en la ley y el estatuto, la gestión de los negocios sociales, lo que implícitamente conlleva a que deben estar informados para ello. ¿Cómo ejercen los accionistas con derecho a voto esta facultad? A través de los siguientes derechos: a) tener a su disposición la información objeto de la Junta desde el día en que fue convocada, b) impugnar acuerdos de la Junta, c) solicitar la nulidad de acuerdos de la Junta, d) requerir auditoría externa anual, e) pedir auditorías especiales, f) solicitar copias certificadas de actas de Junta, etc.

2.2. El derecho de información de las actividades y gestión de la sociedad de los accionistas sin derecho a voto

En el caso de los accionistas sin derecho a voto, el numeral 2 del artículo $96^{(2)}$ de la LGS es mucho más explícito, pues no solamente señala expresamente dicha facultad (extendiendo su amplitud a las actividades y gestión de la sociedad), sino que también establece la periodicidad para ejercerla al definir que cuando menos debe estar informado semestralmente.

\subsection{Información fidedigna del Directorio y del Gerente al emitir constancias}

A su vez, el artículo $175^{(3)}$ de la LGS obliga al Directorio a proporcionar a los accionistas las

(1) Ley General de Sociedades. Artículo 95.- Acciones con derecho a voto La acción con derecho a voto confiere a su titular la calidad de accionista y le atribuye, cuando menos, los siguientes derechos:

1. Participar en el reparto de utilidades y en el del patrimonio neto resultante de la liquidación;

2. Intervenir y votar en las juntas generales o especiales, según corresponda;

3. Fiscalizar en la forma establecida en la ley y el estatuto, la gestión de los negocios sociales;

4. Ser preferido, con las excepciones y en la forma prevista en esta ley, para:

a) La suscripción de acciones en caso de aumento del capital social y en los demás casos de colocación de acciones; y

b) La suscripción de obligaciones u otros títulos convertibles o con derecho a ser convertidos en acciones; y,

5. Separarse de la sociedad en los casos previstos en la ley y en el estatuto.

(2) Ley General de Sociedades. Artículo 96.- Acciones sin derecho a voto

La acción sin derecho a voto confiere a su titular la calidad de accionista y le atribuye, cuando menos, los siguientes derechos: 
informaciones suficientes, fidedignas y oportunas que la LGS determine respecto de la situación legal, económica y financiera de la sociedad. Finalmente, el inciso 5 del artículo 188 de la LGS obliga al Gerente General a expedir constancias y certificaciones respecto del contenido de los libros y registros de la sociedad.

\subsection{Derecho de información del accionista en Grupos de Sociedades}

Poco se ha escrito al respecto, pues si bien los Grupos de Sociedades no son novedosos y son cada vez más frecuentes en la realidad peruana, lo cierto es que cabe preguntarse si el derecho de información de los accionistas les permite a estos acceder a información referente a sus empresas vinculadas. En España, con fecha 21 de mayo de 2012, el Tribunal Supremo dictó una sentencia casacional, la número $324 / 2012$, por medio de la cual determinó que el derecho de información del accionista no le permite acceder a la información correspondiente a las empresas que forman parte del Grupo Económico del cual se es accionista. Vilá comentó la citada jurisprudencia así:

"Esta sentencia entra a valorar la información a la que tiene derecho el accionista de una sociedad sobre las empresas participada por esta, y en particular si el derecho de "información documental" del socio de la holding - que no solo tiene finalidad instrumental en relación con el ejercicio del derecho de voto- comprende el de que sean entregados el Balance, Cuenta de Pérdidas y Ganancias, junto con la Memoria, y demás documentos que integran las respectivas cuentas anuales incluidas en la consolidación. El accionista en cuestión reclamó al BSCH el Balance, Cuenta de Pérdidas y Ganancias, junto con la Memoria, y demás documentos que integran las respectivas cuentas anuales así como el informe de auditoría de las sociedades instrumentales antes de la Junta General Ordinaria de Accionistas del Banco. Dicha petición fue contestada en sentido negativo argumentando que dicha información no entraba dentro de aquella a la que como accionista del Banco tenía derecho. La intención del accionista era demostrar las extrañas circunstancias contables que se producian en las sociedades instrumentales del Banco sin que existiera ninguna explicación por parte de BSCH al respecto." (Vilá Abogados 2012)
Añade Vilá que "entendía el demandante que al ser sociedades instrumentales creadas por el Consejo de Administración y sometidas únicamente al control del mismo debían de ser sometidas al control de la Junta evitando que se produjera opacidad y situaciones de incertidumbre para los accionistas." (Vilá Abogados 2012)

Si bien es válido señalar que el Directorio (en España denominado Consejo de Administración) es el órgano que seguramente aprobó la creación de las subsidiarias, estas son personas jurídicas autónomas que cuentan con sus propios órganos de gobierno. $Y$ en lo que refiere a la Junta General de Accionistas, que si bien puede o no ser mayoritariamente controlada por la matriz, es muy posible que también comparta el accionariado con personas distintas al Grupo de Sociedades, las que velarán por que la información pertinente a la subsidiaria sea difundida al interior del seno social. Lo mismo ocurrirá si el Directorio no está completamente integrado por directores nombrados por el Grupo de Sociedades.

\subsection{El derecho de información del accio- nista en el Código de Buen Gobierno Cor- porativo}

El 8 de noviembre de 2013 se publicó en el diario El Peruano el Código de Buen Gobierno Corporativo para las Sociedades Peruanas, que si bien no es de obligatorio cumplimiento para estas, les brinda una serie de recomendaciones para mejorar la transparencia al interior de las mismas, procurando generar un clima de confianza a los inversionistas. Es por ello que cabe rescatar aquellos principios que se encuentran en dicho código y que están relacionados al derecho de información del accionista. En particular, cabe mencionar

1. Participar en el reparto de utilidades y en el del patrimonio neto resultante de la liquidación con la preferencia que se indica en el artículo 97;

2. Ser informado cuando menos semestralmente de las actividades y gestión de la sociedad;

3. Impugnar los acuerdos que lesionen sus derechos;

4. Separarse de la sociedad en los casos previstos en la ley y en el estatuto; $y$,

5. En caso de aumento de capital:

a) A suscribir acciones con derecho a voto a prorrata de su participación en el capital, en el caso de que la junta general acuerde aumentar el capital únicamente mediante la creación de acciones con derecho a voto.

b) A suscribir acciones con derecho a voto de manera proporcional y en el número necesario para mantener su participación en el capital, en el caso que la junta acuerde que el aumento incluye la creación de acciones sin derecho a voto, pero en un número insuficiente para que los titulares de estas acciones conserven su participación en el capital.

c) A suscribir acciones sin derecho a voto a prorrata de su participación en el capital en los casos de aumento de capital en los que el acuerdo de la junta general no se limite a la creación de acciones con derecho a voto o en los casos en que se acuerde aumentar el capital únicamente mediante la creación de acciones sin derecho a voto.

d) A suscribir obligaciones u otros títulos convertibles o con derecho a ser convertidos en acciones, aplicándose las reglas de los literales anteriores según corresponda a la respectiva emisión de las obligaciones o títulos convertibles. 
el Principio No. 4 ubicado en el Pilar I, y que está referido a la información y comunicación a los accionistas:

"Los accionistas tienen derecho a recibir y requerir información oportuna, confiable y veraz que les permita velar adecuadamente por sus derechos, incluyendo mecanismos de acceso permanente para expresar su opinión sobre el desarrollo de la sociedad.

La sociedad determina los responsables y medios por los cuales oportunamente informa y absuelve los requerimientos de información de los accionistas, tales como páginas web corporativas, oficina de relación con inversionistas, reuniones informativas, entre otros.

La sociedad comunica y pone a disposición de los accionistas la información relacionada con la Junta General de Accionistas, y otra información complementaria que ayude a los accionistas en su toma de decisiones. Los accionistas, cuando corresponda, solicitan informes adicionales o aclaraciones acerca de los puntos a tratar en la Junta General de Accionistas.

Los accionistas son informados acerca de las reglas para alcanzar el quórum, así como acerca de las situaciones que requieren de un quórum calificado."

Por otro lado, los Principios No. $28^{(4)}, 29^{(5)}, 30^{(6)}$ y $31^{(7)}$ dentro del Pilar V (Transparencia de la Información) también buscan desarrollar una estructura ordenada, oportuna, equitativa y previsible para el acceso a la información por parte de los accionistas, recomendando que el Directorio genere políticas de información para estos, los cuales serán atendidos mediante una oficina de relación con los inversionistas. Asimismo, se formulan recomendaciones sobre la elaboración de los Estados Financieros, Memoria Anual, estructura de propiedad, convenios de accionistas y el informe sobre gobierno corporativo.

Si bien, como hemos dicho, la adhesión al citado código es voluntaria y que se podría decir que este se acomoda más a aquellas sociedades con valores inscritos en el Registro Público de Mercado de Valores, no es óbice para que se apliquen a todo tipo de sociedades anónimas.

\section{Clasificación del derecho de información de los accionistas de las sociedades anónimas}

Existen distintas formas de clasificar este derecho de los accionistas de una sociedad anónima. Para este documento nos ceñiremos en aquella que los divide en: (i) el derecho de información para las Juntas Generales de Accionistas y (ii) aquel que se ejerce fuera de ellas.

(3) Ley General de Sociedades. Artículo 175.- Información fidedigna

El directorio debe proporcionar a los accionistas y al público las informaciones suficientes, fidedignas y oportunas que la ley determine respecto de la situación legal, económica y financiera de la sociedad.

(4) Principio 28: Política de información

El Directorio establece en el documento societario respectivo una política de información para los accionistas, inversionistas, demás grupos de interés y el mercado en general, con la cual define de manera formal, ordenada e integral los lineamientos, estándares y criterios que se aplicarán en el manejo, recopilación, elaboración, clasificación, organización y/o distribución de la información que genera o recibe la sociedad.

La política de información abarca toda aquella que pudiera influir en las decisiones económicas de sus usuarios, tales como los objetivos de la sociedad, la lista de los miembros del Directorio y de la Alta Gerencia, la estructura accionaria, la descripción del grupo económico al que pertenece y los estados financieros, entre otros.

El Directorio vela porque la información sea suficiente, veraz y entregada de manera oportuna y equitativa.

La sociedad mantiene una oficina de relación con inversionistas responsable de atender las solicitudes de información, tanto de los accionistas como del público en general. Del mismo modo, la información que se brinda está sujeta a supervisión por un área o instancia facultada a este efecto dentro de la sociedad.

(5) Principio 29: Estados financieros y memoria anual

La sociedad elabora sus estados financieros ciñéndose a las Normas Internacionales de Información Financiera (NIIF), que emita el Consejo de Normas Internacionales de Contabilidad (International Accounting Standards Board, IASB) y que internacionalmente se encuentren vigentes.

EI Directorio aprueba una vez al año la memoria anual de la sociedad, la cual brinda, entre otros aspectos, opiniones u observaciones sobre su desempeño financiero, factores de riesgo relevantes, acontecimientos significativos para la sociedad, relaciones con partes vinculadas y los efectos de las disposiciones o acuerdos de la Junta General de Accionistas.

(6) Principio 30: Información sobre estructura accionaria y acuerdos entre los accionistas

La sociedad revela la estructura de propiedad, considerando las distintas clases de acciones y, de ser el caso, la participación conjunta de un determinado grupo económico.

La sociedad informa sobre los convenios o pactos entre accionistas, incluyendo casos en los que se podría ejercer un control proporcionalmente superior al que deriva de la participación accionaria, así como aquellos asociados a posibles cambios de las reglas internas o estatutarias de la sociedad.

(7) Principio 31: Informe de gobierno corporativo

La sociedad divulga los estándares adoptados en materia de gobierno corporativo en un informe anual, de cuyo contenido es responsable el Directorio, previo informe del Comité de Auditoría, del Comité de Gobierno Corporativo, o de un consultor externo, de ser el caso. 


\subsection{El derecho de información para las Juntas}

El artículo 130 de la LGS $^{(8)}$ prescribe claramente cómo se ejerce el derecho de información de los accionistas en las Juntas, definiendo de la siguiente forma:

- Tiempo: ¿en qué momento se puede ejercer? Desde el día en que se publica la convocatoria a Junta hasta la celebración de la misma.

- Información: documentos, mociones y proyectos relacionados al objeto de la Junta convocada.

- Lugar en el que se podrá acceder a dicha información: en las oficinas de la sociedad o en el lugar de la celebración de la citada Junta.

- Obligado a proporcionarla: el Directorio o la Gerencia si es una Sociedad Anónima Cerrada (SAC) sin Directorio.

- Excepciones: perjuicio al interés social salvo que la solicitud sea formulada por accionistas presentes en la Junta que representen al menos el $25 \%$ de las acciones con derecho a voto.

Es tan relevante que se ejercite adecuadamente el derecho de información de los accionistas en las Juntas que el artículo $131^{(9)}$ de la LGS prevé la posibilidad de aplazar las citadas Juntas cuando estos no se consideren suficientemente informados.

Al respecto, Broseta y Martínez manifiestan lo siguiente:

"con el fin de que los socios puedan emitir convenientemente su voto sobre los asuntos mencionados en la convocatoria de la Junta general, la Ley concede (artículos 196,197 y 272.2 y 3 LSC) a todo socio el denominado derecho de información, el cual reviste dos modalidades. Según la primera, los socios podrán solicitar por escrito, antes de la Junta general, o verbalmente durante la celebración, los informes o aclaraciones que estimen precisos acerca de los asuntos comprendidos en el orden del día de la Junta general; informes o aclaraciones que deberían ser proporcionados por los administradores, de acuerdo con el régimen establecido en los artículos 196 y 197 de la LSC (esto es salvo que a juicio del presidente -S.A.- o del propio órgano de administración -S.L.-, la publicidad de la información perjudique al interés social, a menos que la solicitud provenga de socios que representen el 25 por 100 o más del capital social). De acuerdo con la segunda modalidad, el órgano de administración a partir de la convocatoria de la Junta general ordinaria, a petición de cualquier socio, habrá de entregarle de forma inmediata y gratuita, los documentos que han de ser sometidos a la aprobación de la misma y el informe de los auditores de cuentas (caso de estar la sociedad obligada a verificar sus cuentas), para su examen y análisis, según dispone con carácter imperativo el artículo 272.2 de la LSC. La violación del derecho de información permite, siempre que se pruebe, impugnar los acuerdos que al respecto, y sin respetarlo, haya adoptado la Junta general, puesto que adolecen de nulidad por ser contrarios a la ley. Obviamente, como todos los derechos, también el de información se somete a los límites generales (buena fe, interdicción del abuso de derecho)."(Broseta y Martínez 2014, 418-419)

El énfasis en cursivas es nuestro porque sobre esta aclaración relativa al abuso del derecho trataremos más adelante en el presente artículo, aunque también es menester señalar que ambos autores al tratar el derecho de información de los accionistas únicamente se refieren al denominado "derecho de información en Junta" y no hacen alusión a otro derecho de información que no sea únicamente relacionado a los temas para los que fueron convocados a una Junta.

El derecho de información de los accionistas para las Juntas redunda en importancia cuando

(8) Ley General de Sociedades. Artículo 130.- Derecho de información de los accionistas

Desde el día de la publicación de la convocatoria, los documentos, mociones y proyectos relacionados con el objeto de la junta general deben estar a disposición de los accionistas en las oficinas de la sociedad o en el lugar de celebración de la junta general, durante el horario de oficina de la sociedad.

Los accionistas pueden solicitar con anterioridad a la junta general o durante el curso de la misma los informes o aclaraciones que estimen necesarios acerca de los asuntos comprendidos en la convocatoria. El directorio está obligado a proporcionárselos, salvo en los casos en que juzgue que la difusión de los datos solicitados perjudique el interés social. Esta excepción no procede cuando la solicitud sea formulada por accionistas presentes en la junta que representen al menos el veinticinco por ciento de las acciones suscritas con derecho a voto.

(9) Ley General de Sociedades. Artículo 131.- Aplazamiento de la Junta

A solicitud de accionistas que representen al menos el veinticinco por ciento de las acciones suscritas con derecho a voto la junta general se aplazará por una sola vez, por no menos de tres ni más de cinco días y sin necesidad de nueva convocatoria, para deliberar y votar los asuntos sobre los que no se consideren suficientemente informados.

Cualquiera que sea el número de reuniones en que eventualmente se divida una junta, se la considera como una sola, y se levantará un acta única.

En los casos contemplados en este artículo es de aplicación lo dispuesto en el primer párrafo del artículo 124. 


\section{El abuso del Derecho de Información fuera de Junta en las Sociedades Anónimas y las limitaciones a su ejercicio}

dicho órgano se reúne para aprobar la memoria, los estados financieros y la propuesta de aplicación de las utilidades; es por ello que los artículos $221^{(10)}$ y $224^{(11)}$ de la LGS establecen claramente que dicha información debe estar a disposición de los accionistas a partir del día siguiente de la publicación de la convocatoria a la Junta, inclusive pudiendo obtener gratuitamente copias de dichos documentos. Lo mismo ocurre cuando se tratan de reorganizaciones societarias conforme a lo dispuesto en los artículos $350^{(12)}, 375^{(13)}$ y $393^{(14)}$ de la LGS.

Si la sociedad incumple con proporcionar la información objeto de una convocatoria a Junta, los accionistas quedan expeditos para solicitar la nulidad de la misma, lo que no ocurre cuando se trata de este derecho de información fuera de Junta. Como refiere la doctrina, la omisión en proporcionar los documentos relativos a un punto de la agenda al accionista que lo solicite impide que la Junta pueda abordar la deliberación y voto de dicho tema. Los acuerdos que sobre esta materia se adopten quedan viciados de nulidad, al no estar sustentados en el conocimiento previo que supone la deliberación (Editorial Economía y Finanzas 2018, 204.2).

El informe Winter ${ }^{(15)}$ señaló que la gran importancia que reviste la revelación de información para el gobierno corporativo fue confirmada por las respuestas a la consulta, al menos en lo que concierne a las sociedades que cotizan en bolsa. Estas sociedades deberían, como mínimo, facilitar información acerca de los elementos esenciales de gobierno corporativo que se enumeran en el presente informe. Al ser reclamantes residuales, los accionistas se encuentran en la posición ideal para actuar como vigilantes. Esto es particularmente importante en las sociedades que cotizan en bolsa donde la apatía de los socios minoritarios puede tener efectos perjudiciales. La influencia de los accionistas dependerá en gran medida de los costes y de las dificultades a que se enfrenten. Tradicionalmente, esta influencia se ejercía a través de las Juntas Generales, a las que ya no asisten físicamente muchos accionistas. ${ }^{(16)}$ Hemos resaltado y subrayado dicha precisión, pues con certeza ello debe primar en sociedades cuyo accionariado se encuentra atomizado y en donde los accionistas minoritarios en su gran mayoría fungen de inversionistas en busca de mayores réditos por su inversión que en otros mercados y requieren el mayor nivel de información,

(10) Ley General de Sociedades. Artículo 221.- Memoria e información financiera

Finalizado el ejercicio el directorio debe formular la memoria, los estados financieros y la propuesta de aplicación de las utilidades en caso de haberlas. De estos documentos debe resultar, con claridad y precisión, la situación económica y financiera de la sociedad, el estado de sus negocios y los resultados obtenidos en el ejercicio vencido.

Los estados financieros deben ser puestos a disposición de los accionistas con la antelación necesaria para ser sometidos, conforme a ley, a consideración de la junta obligatoria anual.

(11) Ley General de Sociedades. Artículo 224.- Derecho de información de los accionistas

A partir del día siguiente de la publicación de la convocatoria a la junta general, cualquier accionista puede obtener en las oficinas de la sociedad, en forma gratuita, copias de los documentos a que se refieren los artículos anteriores.

(12) Ley General de Sociedades. Artículo 350.- Requisitos de la convocatoria

Desde la publicación del aviso de convocatoria, cada sociedad participante debe poner a disposición de sus socios, accionistas, obligacionistas y demás titulares de derechos de crédito o títulos especiales, en su domicilio social los siguientes documentos:

1. El proyecto de fusión;

2. Estados financieros auditados del último ejercicio de las sociedades participantes. Aquellas que se hubiesen constituido en el mismo ejercicio en que se acuerda la fusión presentan un balance auditado cerrado al último día del mes previo al de la aprobación del proyecto de fusión;

3. El proyecto del pacto social y estatuto de la sociedad incorporante o de las modificaciones a los de la sociedad absorbente; y,

4. La relación de los principales accionistas, directores y administradores de las sociedades participantes.

(13) Ley General de Sociedades. Artículo 375.- Requisitos de la convocatoria

Desde la publicación del aviso de convocatoria, cada sociedad participante debe poner a disposición de sus socios, accionistas, obligacionistas y demás titulares de derechos de crédito o títulos especiales en su domicilio social los siguientes documentos:

1. El proyecto de escisión;

2. Estados financieros auditados del último ejercicio de las sociedades participantes. Aquellas que se hubiesen constituido en el mismo ejercicio en que se acuerda la escisión presentan un balance auditado cerrado al último día del mes previo al de aprobación del proyecto; 3. El proyecto de modificación del pacto social y estatuto de la sociedad escindida; el proyecto de pacto social y estatuto de la nueva sociedad beneficiaria; $\mathrm{o}$, si se trata de escisión por absorción, las modificaciones que se introduzcan en los de las sociedades beneficiarias de los bloques patrimoniales; $y$,

4. La relación de los principales socios, de los directores y de los administradores de las sociedades participantes.

(14) Ley General de Sociedades. Artículo 393.- Operaciones simultáneas

Las reorganizaciones referidas en los artículos anteriores se realizan en una misma operación, sin perjuicio de que cada una de las sociedades participantes cumpla con los requisitos legales prescritos por la presente ley para cada uno de los diferentes actos que las conforman y de que de cada uno de ellos se deriven las consecuencias que les son pertinentes.

(15) La Comisión Europea creó el Grupo de Alto Nivel de Expertos en Derecho de Sociedades en septiembre de 2001 a fin de que este efectuara recomendaciones acerca de un marco regulador moderno para el Derecho de Sociedades dentro de la Unión Europea, las mismas que fueron recopiladas en el Informe Winter, denominado así en razón de su presidente, el señor Jaap Winter.

(16) Instituto de Censores Jurados de Cuentas de España, "Resumen de las observaciones del Informe Winter", 8 
pues su capacidad de fiscalización o de simplemente asistir a las Juntas es casi nula, considerando que no solamente han colocado su inversión en dicha sociedad objetivo, sino seguramente en muchas otras más.

El citado Informe Winter formuló recomendaciones relacionadas al derecho de información en los siguientes aspectos: (i) Notificaciones y comunicaciones previas a la junta de accionistas - Uso de sitios web: señalando que las sociedades que coticen en bolsa deberían estar obligadas a disponer de una sección específica en sus sitios web en la que publiquen toda la información oportuna para sus accionistas. Dicha sección debería incluir todos los documentos pertinentes relativos a las juntas de accionistas y debería ofrecer medios de otorgar "en línea" poderes de representación o instrucciones de voto o de descargar y transmitir electrónicamente apoderamientos o formularios de instrucciones. (ii) Notificaciones y comunicaciones previas a la junta de accionistas - Derechos de formular preguntas y presentar propuestas de resolución, señalando que las sociedades que coticen en bolsa deberían informar expresamente a sus accionistas del modo en que pueden formular preguntas, de cómo y en qué medida la sociedad tiene intención de responderlas y de cómo y en qué condiciones aquellos pueden presentar propuestas a la junta de accionistas. Esta información debería formar parte de su declaración obligatoria anual de gobierno corporativo. ${ }^{(17)}$ Cabe reiterar que las recomendaciones se refieren únicamente a las sociedades que cotizan en bolsa a pesar de que el alcance del citado informe Winter abarcó todas las sociedades.

\subsection{El derecho de información fuera de Junta}

Como hemos observado, el derecho a la información de los accionistas se encontraba claramente regulado en los artículos mencionados de la LGS. No obstante, con la promulgación y publicación el 28 de julio de 2010 de la Ley 29566, en particular el artículo segundo de la misma, se incorporó el artículo 52-A de la LGS, nombrado como "Derecho del accionista a información fuera de junta" y que a la letra dice lo siguiente:

"Artículo 52-A.- Derecho del accionista a información fuera de junta

Las sociedades anónimas deberán proporcionar en cualquier oportunidad, a solicitud escrita de accionistas que representen al menos el cinco por ciento (5\%) del capital pagado de la sociedad, información respecto de la sociedad y sus operaciones, siempre que no se trate de hechos reservados o de asuntos cuya divulgación pueda causar daños a la sociedad.

En caso de discrepancia sobre el carácter reservado o confidencial de la información, resuelve el juez del domicilio de la sociedad."

- Tiempo: ¿en qué momento se puede ejercer? En cualquier momento. No depende de si existe convocatoria a Junta.

- Información: respecto de la sociedad y de sus operaciones.
- Requisito: solicitud escrita de accionistas que representen el $5 \%$ del capital pagado.

- Obligado a proporcionarla: el Directorio o la Gerencia si es una Sociedad Anónima Cerrada (SAC) sin Directorio.

- Excepciones: que no se trate de hechos reservados o de asuntos cuya divulgación pueda causar daños a la sociedad. En caso de discrepancia sobre la naturaleza de la información es dirimida por el juez del domicilio de la sociedad o mediante el arbitraje de existir convenio arbitral.

Si bien el detalle de que este artículo sea uno de los pocos en la LGS que incluye una letra parece no ser relevante, nos puede llevar a entender lo complicado que pudo ser para los legisladores ubicar dentro de la LGS lo que buscaban decretar.

Para entenderlo, debemos precisar que el artículo 52 de la LGS corresponde al "capital y la responsabilidad de los socios" y está ubicado en el Título Único denominado "Disposiciones Generales" de la pequeña Sección Primera del Segundo Libro sobre la sociedad anónima. Dicho Título solamente constaba de dos artículos, el ya mencionado 52 y el 51, referido a la denominación de la sociedad anónima. Como se puede observar, consideramos que independientemente del análisis que realizaremos sobre el contenido de este derecho, la ubicación del mismo no es la mejor. En efecto, la propia LGS tiene una Sección (tercera) referida a las acciones, dentro de los cuales se encuentran los ya comentados artículos 95 y 96 que detallan los derechos mínimos que gozan los accionistas con y sin derecho a voto. De igual manera, el citado artículo 130 de la LGS precisa el derecho de información de los accionistas en Junta, en donde se pudo haber añadido uno o dos párrafos adicionales para incorporar este nuevo derecho a los accionistas de las sociedades anónimas ordinarias (SA) y las sociedades anónimas cerradas (SAC).

Ahora bien, ¿cuál es el origen de este artículo? Al respecto, debemos remontarnos al Proyecto de Ley No. 3742/2009-PE presentado el 07 de diciembre de 2009 cuya exposición de motivos señalaba que mediante este proyecto de ley, entre otras cosas, se buscaba dotar de disposiciones especiales para la protección

(17) "Resumen de las observaciones del Informe Winter", 12 


\section{El abuso del Derecho de Información fuera de Junta en las Sociedades Anónimas y las limitaciones a su ejercicio}

de los accionistas minoritarios en empresas que cotizan sus acciones en bolsa, asegurando el derecho de los inversionistas a ser informados adecuadamente de la marcha societaria y de todos los actos o acuerdos que puedan causarles perjuicios económicos y facultarlos para tomar acciones legales para resarcir dichos perjuicios. Así, a la letra decía lo siguiente:

"el artículo tercero de dicho proyecto proponía otorgar el derecho a las sociedades con acciones inscritas en rueda de bolsa, a solicitar información fuera junta, siempre y cuando represente al menos el cinco por ciento (5\%) del capital pagado de la sociedad y que el accionista demandante pueda requerir información de forma genérica o específica, a través del juez competente. Este derecho se encuentra recogido en el artículo 261 de la Ley General de Sociedades, para las sociedades anónimas abiertas, a fin que los accionistas puedan tener acceso a la información necesaria para analizar la eficiencia y rentabilidad de su inversión." (la cursiva es del autor).

Sobre el particular, creemos que dicho derecho no le corresponde a las sociedades sino a sus accionistas pero por otro lado coincidimos con el objetivo de extender el derecho otorgado a los accionistas de las sociedades anónimas abiertas (SAA) que estaba regulado en el artículo 261 de la LGS, a los accionistas de todas las sociedades que cotizan sus acciones en bolsa. Ello porque bajo nuestra legislación y, tal como lo demuestra la realidad, no es necesario ser una sociedad anónima abierta (SAA) para tener acciones inscritas en el Registro Público de Mercado de Valores y consecuentemente cotizar dicho valores en bolsa, sino que existen sociedades anónimas ordinarias (SA) que también lo hacen. Lo que sí está proscrito es que las sociedades anónimas cerradas (SAC) lo hagan, tal como lo señala el artículo 234 de la LGS.

Empero, dicho proyecto fue modificado y así presentado al pleno del Congreso para su posterior aprobación, tal como lo recoge el Dictamen de la Comisión de Economía, Banca, Finanzas e Inteligencia Financiera de fecha 21 de abril de 2010 , que señaló lo siguiente:

"se ha considerado pertinente introducir modificaciones directas a la Ley General de Sociedades (a través de una disposición referida al derecho del accionista a información fuera de junta) para ampliar el derecho de acceso a la información a todas las sociedades. Actualmente la referida Ley solo prevé este derecho para las sociedades anónimas abiertas. En tal sentido, se plantea incorporar el artículo 52-A a la Ley General de Sociedades para establecer que: (...)"

De esa forma, sin más motivación que el hecho de señalar que dicho derecho era exclusivo para las sociedades anónimas abiertas (SAA), se modificó el citado Proyecto de Ley y se amplió el denominado "derecho de información fuera de junta", ya no solo para los accionistas de sociedades que cotizan en bolsa, sino para todas las sociedades anónimas, valga decir, también para la sociedad anónima (SA) y la sociedad anónima cerrada (SAC).

Y hacemos la precisión de que este derecho es nuevo para los accionistas de la sociedad anónima (SA) y la sociedad anónima cerrada (SAC) porque los accionistas de las sociedades anónimas abiertas (SAA) siempre gozaron de dicha prerrogativa. Efectivamente, el original artículo 261 de la LGS, señalaba lo siguiente:

"Artículo 261.- Derecho de información fuera de Junta

La sociedad anónima abierta debe proporcionar la información que le soliciten, fuera de junta, accionistas que representen no menos del cinco por ciento del capital pagado, siempre que no se trate de hechos reservados o de asuntos cuya divulgación pueda ocasionar daño a la sociedad.

En caso de discrepancia sobre el carácter reservado o confidencial de la información resuelve la Comisión Nacional Supervisora de Empresas y Valores."

Este artículo fue derogado por la Cuarta Disposición Complementaria Modificatoria de la Ley No.29872, publicada el 28 de julio de 2011.

Al respecto, señala Elías:

“(...) Al reconocerse la condición de inversionistas a los accionistas de la sociedad anónima abierta, resulta evidente que ellos deben tener acceso a la información necesaria para analizar la eficiencia y rentabilidad de su inversión. De otro lado el ausentismo propio de las sociedades de accionariado difundido determina que el derecho de información que debe ser ejercido en el seno de la junta general de accionistas, tenga que ser variado hacia otros mecanismos prácticos que permitan su ejercicio."(Elías 1998, 524)

Es pertinente el comentario de Elías, pues se trata de una sociedad anónima abierta (SAA), en la que el accionista es calificado como un inversionista y, consecuente, siendo ajeno a la administración de la sociedad, le asiste este derecho fuera de Junta.

De la misma forma, Amico expresaba lo siguiente con respecto al artículo 261 de la LGS:

"La exigencia en cuanto al número de accionista se explica en razón a evitar que la sociedad esté expuesta a una permanente investigación por parte de sus numerosos accionistas, al margen de las dificultades de orden administrativo y económico que conllevaría dar curso a las 
solicitudes individualmente planteadas por un gran número de ellos" (Amico 2003, 456).

El autor resalta el umbral de $5 \%$ del capital pagado determinado por la LGS en relación a una de las características más importantes de una sociedad anónima abierta (SAA), como lo es la atomización de su accionariado, distribuido entre un gran número de accionistas.

Igualmente, Morales y Castillo se refieren al derecho de información fuera o dentro de la Junta señalando lo siguiente:

“(...) No obstante lo mencionado, al igual que las legislaciones modernas, nuestra LGS a efectos de evitar excesos en el ejercicio de este derecho, ha limitado al acceso a documentos e informes que en ella se señalan (salvo que el estatuto voluntariamente amplíe los supuestos), no pudiendo ejercerse en forma irrestricta.

En efecto, puede acontecer que se trate de información que pueda perjudicar negocios en marcha o que favorezca a competidores (infiltrados en la sociedad con un porcentaje escaso de acciones), por lo cual el directorio puede negarse a entregarla invocando su conflicto con el interés social (Art. 130 LGS)." (Morales y Castillo 2001, 219)

\section{Limitaciones al Derecho de Información fuera de Junta}

Cabe reiterar que el derecho de información fuera de Junta que goza todo accionista de una sociedad anónima es un medio que le permite a este, ejercer otros derechos, como lo es el derecho a solicitar una auditoría especial o a promover la pretensión de responsabilidad contra uno o más directores. No obstante, el ejercicio de dicho derecho no puede permitirles a los accionistas que priorizan su interés personal frente al interés social, obstruir la correcta marcha de la sociedad. Coincide Amico al señalar que:

"(...) sin perjuicio del reconocimiento del socio a ser informado sobre las actividades y el patrimonio de la sociedad, la normativa societaria suele establecer limitaciones en cuanto a tal derecho, fundamentalmente con el propósito de evitar un ejercicio abusivo del mismo o que como consecuencia de tal ejercicio, por tratarse de información secreta o reservada, pueda verse perjudicada la sociedad por el indebido uso que se haga de la misma" (Amico 2003, 454).

Ahora bien, volviendo al artículo 52-A de la LGS, podemos observar que el mismo no explica claramente el espectro de información al que tiene derecho el accionista, pues simplemente menciona que se trata de "información respecto de la sociedad y sus operaciones", lo cual a todas luces es bastante amplio.

Muro, al comentar el derecho de información de los accionistas contemplado en la LGS, cuando esta no contenía el artículo 52-A, señalaba lo siguiente:

“(...) nos parece que no debería existir inconveniente alguno para que el derecho de información fuera de junta pueda ser ejercido -con las regulaciones y limitaciones del caso- por los socios de sociedades constituidas bajo regímenes societarios distintos al de la sociedad anónima abierta, en las que igualmente puede haber un número importante de socios que, por diversos motivos, no tienen a su cargo la gestión de la sociedad y desde luego tampoco el conocimiento sobre la marcha, pormenores y resultados de dicha gestión." (Muro 1999, 304)

Como bien menciona Muro, dicha asimetría en la información está pensada para aquellos accionistas que no tienen a su cargo la administración de la sociedad.

Asimismo, Hundskopf, que considera que "el derecho de información se encuentra vinculado con el de voto", inclusive tratándose de ejercer dicho derecho para efectos de información relacionada a una Junta en particular, manifiesta lo siguiente:

"Finalmente, debemos indicar que el derecho de información de los accionistas no es irrestricto, sino que debe ejercerse de buena fe y con la intención de contar con mayores elementos de juicio para participar en las juntas. Hacemos esta salvedad porque la posesión de cierta información por parte de accionistas inescrupulosos, obtenida en virtud del derecho aquí comentado podría poner en peligro a la sociedad, e incluso servir para revelar secretos industriales o comerciales a sociedades competidoras.

Hacemos esta salvedad porque la posesión de cierta información por parte de accionistas inescrupulosos, obtenida en virtud del derecho aquí comentado, podría poner en peligro a la sociedad, e incluso servir para revelar secretos industriales o comerciales a sociedades competidoras.

Compete al directorio de las sociedades anónimas analizar en cada caso concreto, la procedencia de entregar la información solicitada por los accionistas." (Hundskopf 1999, 305-306)

Evidentemente, al ser el derecho de información de los accionistas un derecho subjetivo, constituye un límite el abuso del mismo.

De la misma manera, Arbe coincide en establecer que el derecho de información de los accionistas no es irrestricto al señalar lo siguiente: 
“(...) No obstante lo antes expuesto, el derecho de información de los accionistas no tiene un carácter irrestricto y debe ser ejercitado en concordancia con la ley, el estatuto y los intereses de la sociedad.

No puede ser ejercido abusivamente (en contra de los intereses de la sociedad), toda vez que ello conllevaría a distorsiones, a abusos, y demás circunstancias que afectarían la eficiencia de la sociedad. Por dicho motivo, el ejercicio de este derecho debe basarse en la buena fe que deben mantener los accionistas frente a la sociedad; así como al amparo de un interés legítimo." (Arbe 2004, 5)

Añade Arbe al referirse al derecho de información dependiendo del tipo de sociedad:

"La regulación del derecho de información no ha sido ajena a la preponderancia de las mayores características personales o capitalistas de las clases de sociedades antes descritas. Así, en aquellas clases de sociedades anónimas donde el aspecto personal de los accionistas resulta ser relevante, es decir, donde se presume que los socios tienen una participación activa en la gestión de la misma, el derecho de información recoge estándares mínimos relacionados principalmente a la toma de decisiones en la junta general de accionistas. Por el contrario, el carácter eminentemente capitalista de la sociedad anónima abierta que se refleja en la poca o casi nula participación de la mayoría de sus accionistas en su gestión, el derecho de información ha superado los indicados estándares brindándole a los accionistas el derecho a acceder a información que va más allá de las decisiones a ser adoptadas en la junta general de accionistas." (Arbe 2004)

Una limitación incuestionable es que el ejercicio del derecho de información fuera de Junta por parte de los accionistas no afecte la gestión social. Esta limitación la tienen también los directores de las sociedades anónimas, quienes gozan de la facultad de ser informados por la gerencia de todo lo relacionado con la marcha de la sociedad siempre que (i) sea ejercida en el seno del directorio y (ii) no afecte la gestión social, tal como lo prescribe el artículo 173 de la LGS. Elías comenta al respecto: "como es evidente, el derecho de información debe ser ejercido en forma mesurada, de tal manera que no interrumpa las funciones de los gerentes y por ende la actividad de la sociedad" (Elías 1998, 613).

\subsection{El derecho a la información fuera de Junta, ¿es un derecho irrestricto?}

Todo lo dicho anteriormente nos guía hacia un derecho que no es irrestricto, tal como Morales y Castillo lo manifiestan:

"En conclusión en las sociedades anónimas en general los accionistas no gozan de un derecho irrestricto a la información, sino respecto de 'Hechos de Importancia' vinculados generalmente a acuerdos de Junta General, los cuales son conocidos mediante ciertos documentos y mecanismos previstos en la LGS. Las sociedades anónimas abiertas tienen mecanismos de mayor transparencia generalmente vinculados a la realidad de su accionariado difundido y a su intervención en el Mercado de Valores." (Morales y Castillo 2001, 224)

Por su parte, Ramos confirma el postulado de que el derecho de información tiene límites y se expresa de la siguiente manera:

"El derecho de información del accionista no es irrestricto, sino que debe ejercerse de acuerdo con los principios de la buena fe y con la intención de contar con mayores elementos de juicio para participar en las juntas o para ejercitar en forma eficiente algún otro derecho que le reconoce la ley.

La intención del legislador, al restringir el derecho de información, ha sido evitar que se entorpezca la marcha normal de la sociedad como consecuencia de una excesiva intervención de los accionistas y de un uso indiscriminado del derecho de información" (Ramos 2007). (la cursiva es del autor)

Igualmente agrega Ramos refiriéndose al ejercicio abusivo del derecho de información de los accionistas:

“(...) La doctrina reconoce el derecho de información del accionista siempre que lo anime en su ejercicio motivos fundados y que el acto se realice dentro de las condiciones razonables de tiempo y lugar. La sociedad debe actuar con sabia discreción al otorgar al accionista dicho derecho; en tal sentido, no deberá hacerse lugar a la petición cuando ella lleva propósitos de especulación, o busque tan sólo satisfacer una curiosidad, o se dirija a proveer de armas a un chantajista; asimismo, existen accionistas que pretenden el acceso a los libros y papeles de la sociedad con el único objeto de molestar o crear dificultades a los administradores. La suspicacia, el rencor o un simple espíritu de curiosidad llevan, a veces, a verdaderos excesos." (Ramos 2007)

Otro punto a tomar en cuenta en los límites al derecho de información de los accionistas es el relacionado a la información secreta o confidencial. Ramos opina al respecto:

“(...) Por importante que sea el derecho de información, no puede ser absoluto y sin límites; se debe tener en cuenta el interés que tiene la empresa de sobrellevar sus actividades con discreción, o sea, con el respeto del secreto de sus negocios. 
Este secreto puede tener unos objetos diversos: proceso de fabricación, técnicas de comercio, etc. Una transparencia total constituiría un grave peligro: la parálisis de la iniciativa individual en materia económica, ya que resultaría más rentable la iniciativa ajena para sacarle provecho. El criterio de confidencialidad debe ser entonces la utilidad de la información para la viabilidad de la empresa o, inversamente su peligro en caso de ser divulgada." (Ramos 2007)

Dicho argumento busca comprender por qué antes de la incorporación del artículo 52-A en la LGS únicamente en la sociedad anónima abierta se otorgaba un derecho de información a los accionistas fuera de Junta, a diferencia de la sociedad anónima ordinaria y la sociedad anónima cerrada.

Ramos considera que para aquellas sociedades obligadas a transparentar su información debido a que están reguladas por las normas del mercado de valores, el derecho individual del accionista es desplazado por el derecho de los intervinientes en el mercado de valores:

"En las sociedades anónimas abiertas, del mero derecho tradicional a la información del accionista, se pasa a un verdadero deber de carácter más general asumido por la sociedad, en cuanto ésta se ve abocada a suministrar informaciones de carácter público a las que también tenga fácil acceso cualquier persona interesada que así lo desee.

Existe un desplazamiento del centro de gravedad desde la información privada como individual del accionista, a la publicidad informativa como deber general de la sociedad de comunicar al público los datos más relevantes sobre la situación patrimonial y sobre la rentabilidad de la empresa, lo que indica que se ha producido en la nueva política de información, como instrumento al servicio, no sólo de los socios, sino del público interesado más o menos directamente, en la marcha de la sociedad.

El Derecho de sociedades se ha visto impregnado por la regla de la total publicidad, por un principio peculiar del mercado de valores (full disclosure) que, desde su aparición en la legislación estadounidense de los años treinta, ha ejercido una significativa influencia en un buen número de los restantes ordenamientos societarios. De esta manera, la información societaria deja de ser estrictamente social para convertirse en una amplia información empresarial, desbordando el cuadro de las relaciones entre la sociedad y los socios para proyectarse sobre la esfera económica, industrial y mercantil en que la sociedad se desenvuelva. En síntesis, el derecho individual se ha convertido en un deber público." (Ramos 2007)

Por otro lado, cuando uno analiza el numeral 2 del artículo 96 de la LGS, relativo a uno de los derechos de los accionistas sin derecho a voto concerniente a ser informado cuando menos semestralmente de las actividades y gestión de la sociedad, se pregunta si este queda subsumido por el nuevo artículo 52-A, pues si realmente un accionista puede ejercer el derecho de información fuera de Junta instaurado por el artículo 52-A de la LGS, ¿cuál es el sentido del numeral 2 del artículo 96 de la LGS?

La Sentencia 531/2013 del Pleno de la Sala Civil del Tribunal Supremo español analizó si el derecho de información del accionista es irrestricto y dictaminó lo siguiente:

“(...) el derecho de información está sujeto al límite genérico o inmanente de su ejercicio de forma no abusiva objetiva $y$ subjetivamente. Ello debe examinarse de forma casuística en función de múltiples parámetros, entre otros, las características de la sociedad y la distribución de su capital, volumen y forma de la información solicitada. Ha de realizarse una ponderación de las diversas circunstancias concurrentes para verificar que el ejercicio del derecho de información no es abusivo."

Añade la citada sentencia al distinguir el tipo de sociedad y en consecuencia la pertinencia y amplitud del derecho de información de los accionistas $^{(18)}$ :

“(...) Correlativamente, mientras más se aleja la sociedad anónima del modelo de sociedad contractualista y personalista del Código de Comercio y más responde a su configuración tipológica de sociedad abierta, menos justificación tiene un acceso directo del socio a una generalidad de soportes y antecedentes de la contabilidad."

Además, como lo prescribe la citada sentencia, para evaluar el abuso de este derecho se analiza la cantidad de información solicitada y su naturaleza ${ }^{(19)}$ :

"(...) Asimismo, ha de valorarse la perturbación que la solicitud de información formulada por el socio supone para el desarrollo de la actividad del órgano de administración, y para la estructura administrativa de la sociedad, por su volumen o complejidad, si bien en este aspecto ha de tenerse en cuenta la facilitación de la gestión documental que suponen las nuevas tecnologías de la informática y la comunicación. Ha de encontrarse también en este extremo

(18) Sentencia 531/2013 del Pleno de la Sala Civil del Tribunal Supremo español

(19) Sentencia 531/2013 del Pleno de la Sala Civil del Tribunal Supremo español, 22-23 
un equilibrio entre los derechos del socio y el gobierno societario a fin de evitar, por un lado, la paralización de los órganos sociales y, por otro, los abusos de poder y la falta de transparencia. En todo caso, las peticiones de documentación que por su desproporción muestren claramente estar encaminadas a no poder ser atendidas por la sociedad $y$, ante la mínima insatisfacción, provocar un motivo de impugnación de los acuerdos, tienen carácter abusivo".

\subsection{El derecho a la información fuera de Junta, ¿es un derecho a auditar? \\ Sobre este tema, De Carlos $^{(20)}$ expresa lo siguiente:}

"El Tribunal Supremo, en su sentencia núm. 1141/2003 de 3 diciembre (La Ley 201606/2003) destaca que el derecho de información 'no autoriza en manera alguna al accionista a investigar en la contabilidad y en los libros sociales y menos aún en toda la documentación de la sociedad'.

En el mismo sentido se expresa el Alto Tribunal en su sentencia de 22 de mayo de 2002 (La Ley 5896/2002) confirmando que 'tal derecho de información ha de recaer sobre extremos concretos del orden del día de la junta general y no sobre una diversa y completa documentación contable'.

Y la Audiencia Provincial de Murcia (Sección 4. ${ }^{\text {) }}$, en su sentencia núm. 230/2011 de 28 abril (La Ley 77995/2011), concluye:

'Frente a esta primera alegación procede decir que no se produjo vulneración del derecho de información de los actores, ya que antes de la Junta General, la documentación solicitada no respondía a la finalidad prevista en el art. 112 de la Ley de Sociedades Anónimas por tratarse de soportes contables, cuyo conocimiento y control se reserva a los auditores.'(...)".

En el mismo orden de ideas, Ramos se expresa de la siguiente manera:

"La ley ha elaborado un sistema consistente en vedar al accionista el derecho a tomar directamente de la fuente de información datos como por ejemplo de los libros de contabilidad y sociales, ya que de por si no contiene datos ordenados para cualquier fin legítimo del accionista; es por ello que los artículos 226 y 227 de la ley establece que el derecho de información de los accionistas sobre los libros contables se efectúa por medio de Auditores, o sea en forma indirecta. Por otro lado, se debe evitar que estos libros estén a merced de cualquier persona que haya adquirido sus acciones con la finalidad de obtener secretos de la contabilidad social y aprovecharse de este conocimiento con fines de espionaje o de competencia a favor de otra persona" (Ramos 2007).

Morales y Castillo confirman que el derecho de información no implica revisar la contabilidad al señalar lo siguiente:
“(...) Como puede apreciarse, el Derecho de Información de los accionistas de las sociedades anónimas, se ejerce con ocasión de la existencia de una Junta General de Accionistas, ya sea en forma previa, durante el transcurso o en forma posterior a la celebración de la misma, salvo el caso de las sociedades anónimas abiertas, conforme veremos más adelante. Ello por una sencilla razón, no se ha optado por un criterio irrestricto para que el socio ejerza su derecho a la información accediendo a todo dato menudo, revisando los libros contables y efectuando una supervisión al detalle de la gestión social; sino por el contrario se ha canalizado su derecho a través de los procedimientos previstos en la Ley.

Esto significa brindar información trascendente y esencial, vale decir sobre "hechos de importancia" generalmente ligados a decisiones que se han ventilado en Juntas Generales. "Hechos de Importancia" que se conocen a través de los documentos que menciona la ley (mociones, proyectos, informes, aclaraciones memorias, balance general, estado de ganancias y pérdidas, propuesta de aplicación de utilidades, proyectos de reorganización societaria, convocatorias, procedimientos de suscripción preferente, actas de Juntas Generales de Accionistas, etc.), sea que se pongan a disposición de los socios o se difundan a través de publicaciones.

La opción legislativa por publicar o poner a disposición de los socios, simplemente responde al costo económico. En principio, el socio que desea retirar la información asume el costo de la copia que solicita, salvo que se trate de los Estados Financieros, Memoria y Propuesta de Aplicación de Utilidades, caso en el que la Sociedad por mandato legal asume el costo de conformidad con lo previsto por el Art. $224^{\circ}$ de la LGS." (Morales y Castillo 2001, 223)

En Colombia, los socios gozan del derecho a inspeccionar libremente los libros y papeles sociales. Al respecto, señala Peña ${ }^{(21)}$ que el ejercicio de este derecho deberá realizarse conforme a lo que establezca la ley para cada

(20) De Carlos Beltrán, Jose Manuel, Análisis jurisprudencial sobre el derecho de información del socio en relación a la aprobación de cuentas, http://www.delucasremon.com/publicaciones/07.pdf, página 3.

(21) Lisando Peña Nossa, De las sociedades comerciales, 7 ma edición (Bogotá: Ecoe Ediciones, 2014), 41 
uno de los tipos societarios y deberá hacerse en las oficinas de la administración que funcionen en el domicilio principal de la sociedad (Código de Comercio de Colombia, artículos 314, 328, 369 y 447$)^{(22)}$.

\section{3. ¿Cabría fijar en la ley las limitaciones al derecho a la información fuera de Junta?}

Es claro que las limitaciones al derecho de información de los accionistas en las sociedades anónimas no están definidas y consecuentemente se deben analizar en cada caso. Al respecto, De Carlos $^{(23)}$ señala lo siguiente:

“(...) Y ello lleva a la Audiencia Provincial de Alicante, en su mencionada sentencia núm. 322/2010, a concluir que 'Ios límites del derecho de información no son invariables y fijos y en cada caso concreto el juzgador, teniendo en cuenta las circunstancias de hecho del caso examinado y la evaluación global de la prueba, es el que ha de moderar equitativamente si se han traspasado o no los límites del derecho de información solicitado por el accionista'.

Por otra parte, las dificultades en la delimitación del derecho vienen también derivadas de su adecuada contestación por parte de la sociedad, lo que de nuevo queda a criterio de los Tribunales atendiendo a las circunstancias del caso. Así lo señala la Audiencia Provincial de Baleares en su ya citada sentencia núm. 171/2011: 'Pero la cuestión es la de cuándo ha de considerarse cumplida la obligación, y para ello ha de atenerse a la mayor o menor complejidad de las cuestiones suscitadas al ejercitar el derecho. Habrá veces en que una elemental información baste objetivamente, y otras que exijan análisis más particularizados'."

De la misma forma, Hundskopf opina que "el derecho de información no es irrestricto, lo hacemos porque su ejercicio no solo debe justificarse por el interés individual sino también por el interés social, pues un ejercicio irrestricto y sin límites podrían causarle daño a la sociedad, razón por la cual las normatividades societarias suelen establecer limitaciones, fundamentalmente con el propósito de evitar un ejercicio abusivo del mismo" (Hundskopf 2016, 61-62).

Concluye De Carlos $^{(24)}$, con respecto al análisis de la jurisprudencia española referida a los límites al derecho de información de los accionistas de una sociedad anónima, lo siguiente:

"Del análisis de las resoluciones judiciales dictadas en desarrollo de estos límites cabe afirmar que:

a) El derecho de información no es un derecho a auditar.

b) Requiere una mínima colaboración del socio que lo ejercita.

c) No se vulnera si el solicitante tiene conocimiento previo de la información.

d) Se valora la existencia de un informe de auditoría."

4.4. ¿Qué ocurre si el accionista que requiere la información fuera de Junta es a su vez director de la sociedad?

Por otro lado, si el accionista que requiere dicha información es, a su vez, director de dicha sociedad o lo ha sido con respecto a la información solicitada, es evidente que el ejercicio del derecho recogido por el artículo 52-A de la LGS conlleva a un abuso del derecho. Así coincide De Carlos(25), quien expresa que no existe vulneración del derecho de información cuando el solicitante tiene conocimiento previo de la misma y precisa que el hecho de ser consejero -que para nuestra legislación resulta siendo el rol de director- implica un conocimiento tal que no

(22) Artículo 314. Derecho de inspección de los socios en la sociedad colectiva. Aun delegada la administración, los socios tendrán derecho de inspeccionar, por sí mismo o por medio de representantes, los libros y papeles de la sociedad en cualquier tiempo.

Artículo 328. Derecho de inspección y pérdida en la sociedad en comandita. El comanditario tendrá la facultad de inspeccionar en cualquier tiempo, por sí mismo o por medio de un representante, los libros y documentos de la sociedad. Pero si tiene un establecimiento dedicado a las mismas actividades del establecimiento de la sociedad o si forma parte de una compañía dedicada a las mismas actividades, perderá el derecho a examinar los libros sociales.

Artículo 369. Derecho de inspección de los socios en la sociedad de responsabilidad limitada. Los socios tendrán derecho a examinar en cualquier tiempo, por sí mismo o por medio de un representante, la contabilidad de la sociedad, los libros de registro de socios y de actas y en general todos los documentos de la compañía.

Artículo 447. Derecho de los accionistas a la inspección de los libros. Los documentos indicados en el artículo anterior, junto con los libros y demás comprobantes exigidos por la ley, deberán ponerse a disposición de los accionistas en las oficinas de la administración, durante los quince días hábiles que precedan a la reunión de la asamblea. Los administradores y funcionarios directivos así como el revisor fiscal que no dieren cumplimiento a lo preceptuado en este artículo serán sancionados por el superintendente con multas sucesivas de diez mil a cincuenta mil pesos para cada uno de los infractores.

(23) José Manuel De Carlos Beltrán, "Análisis jurisprudencial sobre el derecho de información del socio en relación a la aprobación de cuentas", 2

(24) José Manuel De Carlos Beltrán, "Análisis jurisprudencial sobre el derecho de información del socio en relación a la aprobación de cuentas", 6

(25) José Manuel De Carlos Beltrán, "Análisis jurisprudencial sobre el derecho de información del socio en relación a la aprobación de cuentas", 4-5 
le corresponde solicitar más información, sustentando con jurisprudencia española:

“(...) Así lo señala la Audiencia Provincial de Sevilla (Sección 5. ${ }^{a}$ ) en su sentencia núm. 552/2010 de 30 diciembre (La Ley 303773/2010): 'En cuanto al derecho de información del accionista, [...] no puede dejarse de tener en cuenta, como también señala la jurisprudencia, que no puede entenderse en un sentido tan rígido ni tan amplio que pueda servir para obstaculizar o paralizar el funcionamiento correcto y normal de la sociedad, superponiendo a los intereses sociales el particular del accionista que solicita la información, cuando no obedece a una verdadera y real necesidad; que tiene como límite el conocimiento anterior por parte del socio; $y$, finalmente, que la impugnación de los acuerdos sociales por infracción de este derecho no puede realizarse con mala fe o abuso de derecho'.

En el supuesto concreto de que el solicitante sea consejero, se presume que tiene cabal conocimiento de los libros de cuentas y documentos de la sociedad, por lo que no puede alegar vulneración de su derecho de información, salvo claro está, que se probase lo contrario, supuesto de la sentencia del Tribunal Supremo núm. 664/2005 de 26 septiembre (La Ley 13574/2005), en la que se reconoce infracción del derecho de información de un consejero al considerar probado que el Consejo de Administración no se reunía con la periodicidad mensual prevista en los Estatutos y que el consejero se había visto privado 'continuamente de información que por razón de su cargo le correspondía acceder' por lo que 'su integración en el Consejo de Administración resulta más bien nominal que efectiva al no poder ejercer el cargo conforme a la normativa legal correspondiente'.

Pero no es necesario que el socio sea consejero para que se pueda apreciar la existencia de conocimiento previo, sino que éste puede haberse adquirido de muy diversas formas:

a) La Audiencia Provincial de Alicante (Sección 8. $\left.{ }^{a}\right)$, en su sentencia núm. 255/2010 de 1 junio (La Ley 141547/2010) desestima una presunta infracción del derecho de información del demandante al considerar que en su anterior condición de secretario del Consejo de Administración había tenido acceso al contrato de gestión del que ahora solicitaba información, habiendo incluso votado a favor de su ejecución en una junta anterior.

b) Por su parte, la Audiencia Provincial de Murcia, en su antes citada sentencia núm. 230/2011 estima la existencia de conocimiento previo de la información solicitada a través de las diligencias previas seguidas en otro procedimiento en el que el solicitante era parte."

\section{El abuso del ejercicio del Derecho de Información fuera de Junta}

El artículo II del Título Preliminar del Código Civil dispone lo siguiente: "la ley no ampara el ejercicio ni la omisión abusivos de un derecho. Al demandar indemnización u otra pretensión, el interesado puede solicitar las medidas cautelares apropiadas para evitar o suprimir provisionalmente el abuso." Según Rubio, "el abuso del derecho consistiría en un acto en principio lícito, pero que por una laguna específica del Derecho es tratado como no lícito al atentar contra la armonía de la vida social" (Rubio 1987, 22).

Agrega Rubio señalando que el abuso del derecho asume las siguientes características:

- "Es aplicable ante el ejercicio de los derechos subjetivos por los sujetos. En rigor, por tanto, es más propio hablar de "el abuso en el ejercicio de los derechos", que de "el abuso del derecho", frase esta última que puede prestarse a confusiones semánticas porque permite aludir no sólo al derecho subjetivo, sino también al derecho objetivo.

- El abuso ocurre cuando el sujeto ejercita su derecho de manera no prohibida por la legislación positiva, pero agraviando principios del Derecho que pueden resumirse en la sana convivencia social.

- El abuso tiene así conexión con el reconocimiento de las lagunas del Derecho en nuestra legislación positiva.

- La existencia del abuso, y la medida correctiva pertinente, son determinadas por el magistrado judicial en aplicación de integración jurídica." (Rubio 1987, 25)

Sobre este último literal, cabe citar a Espinoza, quien al referirse al abuso del derecho manifiesta lo siguiente:

“(...) en tanto principio general, es un instrumento del cual se vale el operador jurídico para lograr una correcta y justa administración de justicia. Es aquí donde juega un rol decisivo la labor creativa y prudente del juez que debe estar atento a reconocer nuevos intereses existenciales y patrimoniales, enfrentando audazmente modelos legislativos que los pretenden inmovilizar" (Espinoza 2011, 177).

Y es que el derecho de información de los accionistas fuera de Junta o para esta, así como cualquier otro derecho, no puede ser objeto de abuso por parte de su accionante $y$, en particular, en lo concerniente a este derecho de las minorías, Hundskopf expresa lo siguiente: 
"(...) consideramos que los derechos de los accionistas, cualquiera que sea la clasificación que se use, no pueden ser utilizados para obstaculizar la consecución de los fines y el funcionamiento de la sociedad, ni para interponer el interés personal e individual sobre el interés social, es decir, que el interés general no podrá ser sacrificado en cuanto representa el interés social, para dar pase al interés personal, y al ánimo de lucro del accionista individual. Específicamente en lo que se refiere al derecho de información, este constituye uno de los derechos políticos con los que cuenta el accionista a fin de poder fiscalizar la gestión de los negocios sociales y a la administración de la sociedad, y es por ello una importante herramienta de control social" (Hundskopf 1999, 60-61).

Antes de la incorporación del derecho de información fuera de Junta en la LGS ya existían autores como Payet que opinaban a favor de dicha inclusión, pero siempre que esta sea relevante, señalando lo siguiente:

"el derecho de información tiene un tratamiento excesivamente restrictivo en la Ley General de Sociedades. En las sociedades que no tienen la calidad de abiertas, el derecho de información de los accionistas se ejerce en la junta general y se limita a los asuntos materia de la convocatoria. Si bien accionistas con una participación no menor al $20 \%$ de las acciones suscritas con derecho a voto pueden exigir la convocatoria a junta general, esta facultad no está abierta para las minorías que tiene un porcentaje de participación inferior y, en todo caso, la convocatoria a junta general resulta ser un mecanismo engorroso y complicado para el simple acceso a información sobre la marcha de la sociedad. Es cierto como señala Elías Laroza, la regulación del derecho a exigir auditorías especiales en la Ley General de Sociedades tiene una gran amplitud, la disposición en el sentido que las materias objeto de revisión deben ser relativas a los últimos estados financieros puede en la práctica restringir innecesariamente este derecho. Además, el tener que recurrir a una auditoría especial para obtener información relevante parecería fomentar innecesariamente el litigio, al imponer una vía de acceso a la información que podría ser considerada agresiva o conflictiva por la sociedad. Sería más sencillo que, sin perjuicio del derecho a disponer auditorías especiales, se reconozca también el derecho de los accionistas minoritarios de requerir la entrega de la información relevante sin que sea necesario efectuar una auditoría" (Payet 2003, 100).

Añade Payet que:

"(...) se ha dicho que una excesiva amplitud del derecho a la información podría prestarse a abusos de las minorías. Sin embargo, especialmente en el caso de las sociedades con valores objeto de oferta pública, la transparencia debe ser una obligación permanente y absoluta. Evidentemente existe siempre la posibilidad del ejercicio abusivo de un derecho. Sin embargo, esa conducta es antijurídica y el Derecho cuenta con los mecanismos necesarios para ponerle freno. La mera posibilidad del ejercicio abusivo no es motivo suficiente para desconocer un derecho que resulta fundamental para el adecuado manejo de las empresas." (Payet 2003, 100-101)

Sobre el particular, coincidimos con el autor en que dicho derecho debe ser otorgado para los accionistas de sociedades que cotizan en bolsa, pero no compartimos la idea de que ello se amplíe sin mayores limitaciones a sociedades anónimas y sociedades anónimas cerradas que no estén reguladas por la Ley del Mercado de Valores, que fue el espíritu del original artículo 52-A de la LGS.

En Argentina, el artículo 55 de la Ley de Sociedades dispone que "Los socios pueden examinar los libros y papeles sociales y recabar del administrador los informes que estimen pertinentes." Como se observa, el citado artículo no establece limitación alguna al derecho de información del socio, lo que le permite acceder a informarse de los que conste en los libros societarios, así como en la documentación de la empresa.

Sin embargo, dicho derecho tampoco es irrestricto y la doctrina argentina no dista mucho de la nuestra. Grispo considera que:

"en tanto el socio ejerza funcional y prudentemente su derecho de información, no podrá ser objeto de ningún reproche. A fin de conceptualizar ese ejercicio legítimo del derecho a informarse, resultará de vital trascendencia la doctrina y la jurisprudencia elaboradas en torno a la norma del Código Civil previamente citada. Dentro de este marco de actuación (ejercicio debido) no podrá ser negado el acceso a la información requerida por todo socio que así lo solicite". (Grispo 2014)

El autor argentino se refiere al artículo 1071 del Código Civil argentino, que a la letra dispone que:

"El ejercicio regular de un derecho propio o el cumplimiento de una obligación legal no puede constituir como ilícito ningún acto. La ley no ampara el ejercicio abusivo de los derechos. Se considerará tal al que contrarie los fines que aquella tuvo en mira al reconocerlo o al que exceda los límites impuestos por la buena fe, la moral y las buenas costumbres."

Grispo cita interesante jurisprudencia argentina referida al tema, donde destaca la que señala lo siguiente:

"El hecho que una sociedad anónima carezca de órgano de fiscalización de 
acuerdo con lo previsto por la LS art. 284, no significa que necesariamente debe reconocerse al socio el derecho de información previsto por la LS art. 55 en cualquier tiempo y por cualquier cosa sobre los libros y papeles sociales. Por su parte, el control de gestión del directorio en la S.A. se materializa a través del procedimiento de someter periódicamente los estados contables a la asamblea de accionistas, siendo inaceptable la posibilidad de que esa gestión sea evaluada individualmente por cada socio en la ocasión que discrecionalmente elija a ese efecto, pidiendo que se le exhiban los documentos antes citados" (Grispo 2014).

Dicha jurisprudencia pondera el derecho de información de los socios en Argentina y la restringe en tiempo y temática.

Igualmente, Krischcautzky comenta un fallo de la Cámara Comercial Argentina en el caso Farallón Telco Inversora LLC contra Nortel Inversora SA y otros del 28 de mayo de 2002 que determinó que el derecho dispuesto por el citado artículo 55 de Ley de Sociedades Argentina se encontraba limitado al examen de los estados contables del ejercicio y su documentación complementaria. Krischcautzky menciona que:

"los accionistas tienen derecho a pedir la información y la documentación necesarias para participar en las asambleas. Los pedidos de información realizados a la sindicatura deben versar exclusivamente sobre temas que sean de la competencia del órgano de fiscalización y no deben alcanzar los actos de gestión de los administradores. El derecho de información debe ser ejercido por el accionista de buena fe y para un fin determinado, que es el de poder participar en las asambleas debidamente informado. En síntesis, el fallo antes citado establece límites adecuados al interés del accionista en acceder a la información social y la obligación de la sociedad de suministrarle la información"(26).

Al respecto, cabe señalar que la Ley de Sociedades Argentina prevé en algunos casos la sindicatura o consejo de vigilancia, en los cuales los accionistas no pueden acceder a la información de manera directa, sino que deben recurrir al síndico. De esta forma, los accionistas no entorpecerán a los administradores de la sociedad.

Empero también existen voces disidentes en la doctrina argentina como la que propone Riobó, quien señala que:

“(...) no parece que exista obstáculo alguno para reconocer un amplio derecho de información al accionista. El mismo no solo incluye el derecho de acceder a los datos de la contabilidad sino también el de requerir informes al síndico sobre la gestión del directorio. Esto concuerda con la realidad de la anónima argentina en la cual no ocurre, como en otros órdenes jurídicos, una disociación entre poder y propiedad. Son los accionistas que conforman las mayorías en las asambleas quienes designan a los integrantes del directorio encargado de la gestión social. Para evitar que el órgano de administración responda a los intereses particulares del grupo mayoritario en perjuicio del interés social, aparece el derecho de informarse del accionista. Si no se reconociera la atribución del socio minoritario de requerir informes de gestión, no le sería posible advertir y prevenir abusos de poder. Por ello, es necesario fomentar mecanismos de control societario como el derecho aquí expuesto" $(27)$.

\section{6. ¿El derecho de información fuera de Junta aplica para información que se encuentra lista o por preparar?}

Por otro lado, es menester evaluar el significado del término proporcionar, ello porque el artículo 52-A de la LGS obliga a las sociedades anónimas a "proporcionar", es decir, a brindar algo que ya existe, no para elaborarlo o producirlo. Ese algo es la información ${ }^{(28)}$, que para este caso puntual se refiere a la relacionada a la sociedad y a sus operaciones; y se debe entender que se dispone de dicha información ya sea mediante datos, registros, informes, reportes, etcétera.

Por ende, el derecho otorgado a los accionistas que alcancen el $5 \%$ del capital pagado con arreglo a lo dispuesto por el artículo

(26) Diego Krischcautzky, "Derecho de información del accionista”, Estudio Marval, O’ Farrell \& Mairal

(27) María Belén Riobó. "El Contenido del Derecho de Información de los accionistas en la S.A. actual" (ponencia presentada en el VII Congreso Iberoamericano de Derecho Societario y de la Empresa, Mar del Plata, Argentina, 2010)

(28) El Diccionario de la Real Academia de la Lengua Española define el término "información" de la siguiente manera:

1. f. Acción y efecto de informar.

2. f. Oficina donde se informa sobre algo.

3. f. Averiguación jurídica y legal de un hecho o delito.

4. f. Pruebas que se hacen de la calidad y circunstancias necesarias en una persona para un empleo $u$ honor. U. $\mathrm{m}$. en pl.

5. f. Comunicación o adquisición de conocimientos que permiten ampliar o precisar los que se poseen sobre una materia determinada.

6. f. Conocimientos comunicados o adquiridos mediante una información.

7. f. Biol. Propiedad intrínseca de ciertos biopolímeros, como los ácidos nucleicos, originada por la secuencia de las unidades componentes. 8. f. desus. Educación, instrucción. 
52-A de la LGS no implica exigirle a la administración de la sociedad la elaboración de información no existente o que no se encuentre en su poder ni de producir nueva información con data existente o de la cual disponga. En todo caso, la elaboración de nueva información y/o la nueva producción de la misma es prerrogativa de la administración de la sociedad en función de las prioridades que le sugieren sus planes de gestión y sus necesidades de información para la toma de decisiones. Es decir que el artículo 52-A de la LGS no le concede ni autoriza al accionista a exigir a la administración que elabore y/o produzca una nueva información que no exista como tal a la fecha de su solicitud.

Este derecho al accionista minoritario se limita al acceso a la información existente y disponible, no en una prerrogativa de exigir la producción de información o conocimiento, valga decir, datos con valor agregado, que sea de su interés, como por ejemplo, cuadros estadísticos, proyecciones o reportes de todo tipo. Sólo cabría exigir este tipo de información si tales cuadros estadísticos, proyecciones o reportes ya fuesen parte de la información existente en la sociedad y, consecuentemente, formaran ya parte de su acerbo documentario. Lo contrario implicaría que la administración de la sociedad deba preparar dichos cuadros, proyecciones o reportes para cumplir con el pedido especial del accionista interesado. En todo caso, los órganos de administración de la sociedad pueden exigir la generación de información nueva o con valor agregado, a propósito del cumplimiento de su gestión.

Por otro lado, si la norma obliga a proporcionar información, ello supone necesariamente que no haya sido suministrada con anterioridad; de modo que toda información que se le hubiere proporcionado al accionista con ocasión de la celebración de la Junta o en otra oportunidad, o que hubiere estado a su disposición, o aquella información que es pública, o a la que el accionista pudiera acceder por su propios medios, se encuentra excluida de la obligación de proporcionar por parte de la administración de la sociedad.

Al respecto, Yabar opina que:

"si el único requisito para solicitar información a la sociedad es reunir un porcentaje mínimo, entonces significaría que no habría ningún límite para el ejercicio de este derecho lo que podría originar un estancamiento de la eficiencia administrativa de la sociedad. A las tareas normales que esta debe realizar, habría que añadirle la atención y respuesta que esta tendría que destinar a las solicitudes informativas de cada accionista en cualquier momento. Si la demanda de información es masiva, la sociedad se verá obligada a encargar dicha tarea a un área dedicada exclusivamente a ello, destinando recursos humanos y económicos que deberían emplearse para procurar un mayor crecimiento de la sociedad." (Yabar 2010)

Coincide Peró señalando que la obtención de información respecto de la sociedad y sus operaciones, en cualquier momento, por parte de accionistas que representen al menos el cinco por ciento del capital pagado de la sociedad, podría acarrear importantes costos para la administración de la sociedad, para atender las solicitudes de información de los accionistas, con el correspondiente gasto en personal y recursos (Peró 2012, 283). Añade Peró que la posibilidad de que prácticamente cualquier accionista pueda solicitar información en cualquier momento, sin necesidad de sustentarlo y a un escaso costo, es perjudicial para las sociedades anónimas, puesto que podría permitir el abuso del derecho de información por parte de accionistas cuyo objetivo sea entorpecer la marcha de la sociedad (Peró 2012, 284).

\section{EI Derecho de Información fuera de Junta en el Anteproyecto de la Ley General de Sociedades}

El anteproyecto de la Ley General de Sociedades ${ }^{(29)}$ elaborado por el Grupo de Trabajo conformado por Resolución Ministerial 0108-2017-JUS no considera un "derecho de información fuera de junta" tal como está dispuesto por el artículo 52-A de la actual LGS; sin embargo, contiene un "derecho de información general” en su artículo 120.2, que señala lo siguiente:

"120.2. Derecho de información general

Las sociedades anónimas deben proporcionar en cualquier oportunidad, a solicitud escrita de accionistas que representen no menos del cinco por ciento de las acciones emitidas por la sociedad, información respecto de la sociedad y sus operaciones, siempre que esta facultad se use con criterios de buena fe, equidad y proporción y no se trate de hechos reservados o de asuntos cuya divulgación pueda causar daños y perjuicios a la sociedad.

En caso de discrepancia sobre el carácter reservado o confidencial de la información, o sobre un eventual ejercicio desproporcionado o inequitativo del derecho descrito en el literal a) del presente numeral, resuelve el juez del domicilio de la sociedad."

(29) Véase https://legis.pe/anteproyecto-ley-general-sociedades/ 
Como se puede observar, en dicha propuesta de cambio normativo se han incorporado mayores restricciones a este derecho, relacionadas a que el mismo se use con criterios de buena fe, equidad y proporción, manteniendo la condición de que tampoco se trate de hechos reservados o de asuntos cuya divulgación pueda causar daños y perjuicios a la sociedad. Adicionalmente, la facultad de los jueces para dirimir en caso de discrepancia sobre el uso correcto del derecho de información ya no solamente versará sobre el carácter reservado o confidencial de la información, sino que se incluye expresamente que también será sobre un eventual ejercicio desproporcionado o inequitativo de dicho derecho, aunque omite incluir si este se ejerza de mala fe. Empero, esta propuesta no restringe el ejercicio de esta facultad a que no afecte la gestión social, como si lo hace dicho documento en su artículo 150, cuando señala que todo director tiene derecho a recibir de la sociedad la información que considere necesaria para el cumplimiento de sus obligaciones siempre que no afecte la gestión social.

Finalmente, este texto hace una pequeña modificación con referencia al porcentaje necesario para su ejercicio, pues la norma vigente precisa que el cinco por ciento $(5 \%)$ requerido, corresponde al capital pagado de la sociedad; en cambio, esta propuesta relaciona el mismo porcentaje al universo de acciones emitidas por la sociedad, sin hacer diferencia de si están parcial o totalmente pagadas.

\section{Conclusiones}

El derecho de información fuera de Junta es un derecho fundamental de todo accionista de una sociedad anónima. Cuando al interior de las sociedades sus miembros están alineados con el interés social, la información societaria fluye regularmente y les permite a sus órganos de gobierno tomar las mejores decisiones de gestión. Sin embargo, no podemos ser ajenos a la existencia de los conflictos societarios y que una de las características más recurrentes ante este tipo de escenarios es, justamente, la falta de información relevante y oportuna hacia los accionistas minoritarios.

El objetivo inicial del artículo 52-A de la LGS era el correcto; es decir, a través de dicho artículo se buscaba ampliar el espectro de sociedades que contenía el derogado artículo 261 de la LGS, para que no solamente fuesen las sociedades anónimas abiertas las obligadas a proporcionar información fuera de Junta a aquellos accionistas que lo solicitasen, sino que se amplíe también a aquellas sociedades que, a pesar de no ser sociedades anónimas abiertas, también tenían inscritas sus acciones en el Registro Público de Mercado de Valores.

Sin embargo, el otorgar este derecho de información fuera de Junta a sociedades anónimas que desean mantenerse en un ámbito privado y consecuentemente no pretenden registrar sus acciones en el Registro Público de Mercado de Valores, ni que sus valores se coticen en una bolsa, ni estar reguladas por la Superintendencia de Mercado de Valores, ni cumplir con la legislación correspondiente, no puede limitarse únicamente a que sea solicitada por accionistas que representen al menos el $5 \%$ del capital pagado y que la información solicitada no se trate de hechos reservados o de asuntos cuya divulgación pueda causar daños a la sociedad, pues ello puede conllevar a un abuso del derecho por parte de los accionistas solicitantes.

El ejercicio abusivo del derecho de información fuera de Junta colisiona con un correcto y ordenado manejo de la sociedad, cuya administración debe enfocarse en obtener los mejores resultados para esta y no distraerse elaborando información para los accionistas que la requieren, sin mayor limitación que la comentada. Establecer positivamente las limitaciones al derecho de información fuera de Junta no es una tarea fácil; no obstante, se pueden mejorar algunos aspectos de nuestra legislación societaria y quizás tomar como parámetro algunas legislaciones de otros países, como las mencionadas en este artículo. Una de ellas postula que el derecho de información fuera de Junta considera la posibilidad de que los accionistas puedan acceder a los libros contables de la sociedad.

La propuesta de modificación sobre el derecho de información fuera de Junta formulada en el Anteproyecto de la Ley General de Sociedades es un buen avance, pues incorpora la obligación de ejercer dicha facultad siempre que se use con criterios de buena fe, equidad y proporción, empero no precisa que el ejercicio de esta facultad no debe afectar la gestión social.

También se podría limitar el ejercicio de este derecho a información que se encuentre disponible en la sociedad, a efectos de no exigir a la administración la elaboración de reportes que no se encuentran preparados y que de lo contrario conllevaría el uso de recursos para cumplir con ello. Recordemos que los directores gozan de la facultad de requerir al gerente general todo la información que sea necesaria para el mejor ejercicio de su función en el seno del directorio y sin afectar la gestión social.

Otra medida interesante podría ser obligar a la sociedad a poner a disposición de los accionistas la información que corresponde a las Juntas Obligatorias Anuales, así estas no sean convocadas en el plazo de ley o habiéndolo sido, no se realicen. Adicionalmente, se podría tomar en consideración el plazo máximo previsto para la realización de las mismas 
según lo dispone el artículo $114^{(30)}$ de la LGS; es decir, que luego de transcurridos tres meses de terminado el ejercicio económico, la Memoria Anual y los Estados Financieros se encuentren a disposición de cualquier accionista (con o sin derecho a voto) que lo requiera e inclusive esto podría ampliarse una vez más, siguiendo la pauta del inciso 2 del artículo 96 de la LGS referido a los derechos de los accionistas sin derecho a voto y, de esta forma, dicha información también se encuentre disponible para el segundo semestre del año.

Otra variable a utilizar en la limitación del derecho a información fuera de Junta podría ser el tipo de sociedad; es decir, si se trata de una micro, pequeña, mediana o gran empresa, ya sea aumentando el umbral del porcentaje de acciones requerido para el ejercicio del derecho de información fuera de Junta, el nivel de detalle de la información solicitada, etc.

Por otro lado, el derecho de información fuera de Junta debería abarcar de la manera más amplia toda la información relacionada a las operaciones entre empresas vinculadas con la sociedad que desafortunadamente es una de las formas más utilizadas para socavar los derechos de los accionistas minoritarios. Por ejemplo, pero sin ceñirse únicamente a esta, dicha información debería incluir los estudios de precios de transferencia exigidos por la autoridad tributaria.

Sin perjuicio de que se logre una reforma legislativa, cabe señalar que el pacto social, el estatuto o los convenios de accionistas pueden prever condiciones diferentes para el ejercicio del derecho de información fuera de Junta de los accionistas, ampliando el acceso a dicha información y regulando la forma y oportunidad en que pueda ser ejercido.

\section{Referencias bibliográficas}

Amico Anaya, Mateo. 2003. Derecho Societario. Tomo I de Tratado de Derecho Mercantil. 1ra edición. Lima: Gaceta Jurídica

Arbe Saldaña, Cesar. 2004. "Una aproximación al derecho de información de los accionistas". Revista Legal 127 (setiembre): 5

Broseta Pont, Manuel y Martínez Sanz, Fernando. 2014. Vol. 1 de Manual de Derecho Mercantil. 21ra edición. Madrid: Editorial Tecnos

De Carlos Beltrán, José Manuel, Análisis jurisprudencial sobre el derecho de información del socio en relación a la aprobación de cuentas, http://www.delucasremon.com/publicaciones/07.pdf, 3.
Editorial Economía y Finanzas. 2018. Tomo I de Manual Societario. Lima: Editorial Economía y Finanzas

Elías Laroza, Enrique. 1998. Ley General de Sociedades comentada. Lima: Editora Normas Legales

Espinoza, Juan. 2011. Los Principios Contenidos en el Título Preliminar del Código Civil peruano de 1984. Lima: Editorial Grijley

Grispo, Jorge Daniel. Estudio Grispo \& Asociados. "Cuál es el justo límite del derecho de información de los socios en las sociedades comerciales". http://estudiogrispo.blogspot. com/2014/11/cual-es-el-justo-limite-delderecho-de.html

Hundskopf Exebio Oswaldo.1999. Estudios Societarios Ley General De Sociedades. 1ra edición. Lima: Editorial Gaceta Jurídica.

2016. La Sociedad Anónima. Un enfoque teórico y práctico. 1ra edición. Lima: Gaceta Jurídica

Instituto de Censores Jurados de Cuentas de España. Resumen de las observaciones del Informe Winter. https://www.icjce.es/ images/pdfs/TECNICA/B 1\% 20 - \% 20 Comisi $\tilde{A}^{3}$ \%20Europea/B.1.21\%20-\%20CE\%20 -\%20DSyGC \%20-\%20Moderniz\%20legis/ Informe\%20Winter\%20(Trad\%20ICAC)\%20 -\%2004112002.PDF

Krischcautzky, Diego. Estudio Marval, O' Farrell \& Mairal. Derecho de información del accionista. https://www.marval.com/publicacion/derechode-informacion-del-accionista-4910

Morales Acosta, Alonso y Castillo Wong, Maribel. 2001. Hechos de importancia y sociedades anónimas. Revista Peruana de Derecho de la Empresa 52: 219

Muro Rojo, Manuel. 1999. Estudios Societarios Ley General De Sociedades. 1ra edición. Lima: Editorial Gaceta Jurídica.

Payet, José Antonio. 2003. "Empresa, gobierno corporativo y Derecho de Sociedades:

(30) Artículo 114.- Junta Obligatoria Anual

La junta general se reúne obligatoriamente cuando menos una vez al año dentro de los tres meses siguientes a la terminación del ejercicio económico.

Tiene por objeto:

1. Pronunciarse sobre la gestión social y los resultados económicos del ejercicio anterior expresados en los estados financieros del ejercicio anterior.

2. Resolver sobre la aplicación de las utilidades, si las hubiere;

3. Elegir cuando corresponda a los miembros del directorio y fijar su retribución;

4. Designar o delegar en el directorio la designación de los auditores externos, cuando corresponda; y,

5. Resolver sobre los demás asuntos que le sean propios conforme al estatuto y sobre cualquier otro consignado en la convocatoria. 
Reflexiones sobre la protección de las minorías". Themis 46: 77-103

Peña Nossa, Lisando. 2014. De las sociedades comerciales. $7 \mathrm{ma}$ edición. Bogotá: Ecoe Ediciones

Peró Mayandía, Mariano. 2012. "El derecho de información de los accionistas y el artículo 52-A de la Ley General de Sociedades sobre Información fuera de junta". Themis 62: 277-28

Ramos Padilla, Cesar. 2007. "Derecho de Información de los accionistas en la sociedad anónima". Derecho y Cambio Social 12 (diciembre). Consultado en: http://www. derechoycambiosocial.com/revista012/ derecho\%20informacion\%20accionistas.htm

Riobó, María Belén. 2010. El Contenido del Derecho de Información de los accionistas en la S.A. actual. Ponencia presentada en el VII Congreso Iberoamericano de Derecho Societario y de la Empresa, 2010, en Mar del Plata, Argentina. https://repositorio. uade.edu.ar/xmlui/bitstream/handle/123456789/2149/CDS11030105. pdf?sequence $=1$ \&isAllowed $=y$

Rubio Correa, Marcial. 1987. Tomo II de Para leer el Código Civil. Lima: Fondo Editorial de la Pontificia Universidad Católica del Perú

Tribunal Supremo español. 2013. Pleno de la Sala Civil. Sentencia 531/2013. http://estaticos.expansion.com/opinion/ documentosWeb/2013/10/11/sentencia_sa_derecho_informacion. pdf

Yabar, María Eugenia. Enfoque Derecho. ¿Un paso adelante o un paso atrás? 10 de agosto de 2010. https://www.enfoquederecho. com/2010/08/10/un-paso-adelante-o-un-paso-atras/

Vilá Abogados. El derecho de información del accionista en los grupos de sociedades.

https://vila.es/el-derecho-de-informacion-del-accionista-en-losgrupos-de-sociedades/

\section{Benites, Vargas \& Ugaz \\ ABOGADOS}

